\title{
DNA (Cytosine-5)-Methyltransferase 3-Like
}

National Cancer Institute

\section{Source}

National Cancer Institute. DNA (Cytosine-5)-Methyltransferase 3-Like. NCI Thesaurus. Code C148374.

DNA (cytosine-5)-methyltransferase 3-like (386 aa, 44 kDa) is encoded by the human DNMT 3L gene. This protein is involved in the modulation of DNA methyltransferase activity. 